\title{
ANALISIS RASIO PROFITABILITAS PERBAKAN DI INDONESIA (STUDI EMPIRIS PADA BANK BUMN)
}

\author{
Ermaini $^{1}$ \\ Dosen Tetap Universitas Muhammadiyah Jambi ${ }^{1}$ \\ ermaini73@gmail.com \\ Endah Tri kurniasih ${ }^{2}$ \\ Dosen Tetap Universitas Muhammadiyah Jambi ${ }^{2}$ \\ endah.trikurniasih@gmail.com \\ Ade Irma Suryani ${ }^{3}$ \\ Dosen Tetap Universitas Muhammadiyah $\mathrm{Jambi}^{3}$ \\ Trie Hierdawati ${ }^{4}$ \\ Dosen Universitas Muhammadiyah Jambi ${ }^{4}$ \\ triehierdawati09@gmail.com
}

\begin{abstract}
Abstrak
Penelitian ini berfokus pada analisis kinerja keuangan Bank yang berbentuk Badan Usaha Milik Negara (BUMN) yang terdaftar di Bursa Efek Indonesia (BEI) periode 2016 sampai dengan 2020. Tujuan dari penelitian ini yaitu untuk menganalisis perkembangan rasiorasio 4 bank BUMN tersebut. Data yang digunakan dalam penelitian ini yaitu data sekunder yang bersumber dari Annual Report yaitu PT. Bank Rakyat Indonesia Tbk, PT. Bank Negara Indonesia Tbk, PT. Bank Tabungan Negara Tbk dan PT. Bank Mandiri Tbk. Adapun variabel yang dijadikan penelitian yaitu rasio profitabilitas yang terdiri dari rasio NIM, ROA dan ROE. Hasil penelitian menunjukan bahwa rasio - rasio profitabilitas bank BUMN selama periode 2016 sampai 2020 berfluktuatif dan menunjukan trend menurun pada tahun 2020 dikarenakan wabah pandemi covid 19.
\end{abstract}

Kata Kunci: Rasio Profitabilitas, ROA, ROE, NIM dan Bank BUMN

\section{PENDAHULUAN}

Beberapa ahli mendefinisikan pertumbuhan ekonomi (Economic Growth) adalah perkembangan kegiatan dalam perekonomian yang menyebabkan barang dan jasa yang diproduksikan dalam masyarakat bertambah dan kemakmuran masyarakat meningkat (Daniel, 2018). Sedangkan Soleh (2019) juga mendefinisikan pertumbuhan ekonomi merupakan suatu proses dimana terjadi kenaikan produk nasional bruto riil suatu perekonomian riil atau pendapatan riil. Bertolok dari pendapat ahli tersebut dapat disimpulkan bahwa dengan penurunan pertumbuhan ekonomi akan berkibat pada kemakmuran masyarakat yang akan menurun pula. Untuk itu diperlukan suatu upaya untuk dapat meningkatkan pertumbuhan ekonomi Indonesia pada tahun 2021 agar kelangsungan pembangunan ekonomi dapat berlanjut. Pendapat ini sesuai dengan Nurdin (2018) yang mengatakan bahwa pertumbuhan ekonomi yang tinggi dan berkelanjutan merupakan kondisi utama bagi kelangsungan pembangunan ekonomi. 
Upaya untuk meningkatkan pertumbuhan ekonomi dapat dilakukan oleh pemerintah salah satunya yaitu melalui Badan Usaha Milik Negara (BUMN). Terdapat 177 BUMN yang ada saat ini. Salah satu unit usaha yang dijalankan oleh BUMN yaitu Bank. Wiarta (2020) mengemukakan bahwa Pembangunan ekonomi di suatu negara sangat bergantung oleh adanya perkembangan dinamis dan kontribusi nyata di sektor perbankan, alasannya karena kontribusi sektor perbankan berperan penting dalam menggerakkan roda perekonomian di suatu negara. Terdapat 4 buah Bank yang berbetuk BUMN yang terlisting atau terdaftar di Bursa Efek Indonesia. Adapun 4 bank tersebut dapat dilihat pada tabel dibawah ini :

Tabel 1.1

Bank Berbentuk BUMN yang listing di BEI

\begin{tabular}{|c|l|c|}
\hline No. & \multicolumn{1}{|c|}{ Nama Bank } & Kode Perusahana \\
\hline 1 & PT. Bank Rakyat Indonesia Tbk & BBRI \\
\hline 2 & PT. Bank Negara Indonesia Tbk & BBNI \\
\hline 3 & PT. Bank Tabungan Negara Tbk & BBTN \\
\hline 4 & PT. Bank Mandiri Tbk & BMRI \\
\hline
\end{tabular}

Sumber : IDX 2020

Berdasarkan tabel tersebut, didapatkan data mengenai bank BUMN yang terdaftar di BEI merupakan Bank dengan Kapitalisasi pasar yang besar. Berdasarkan data BEI pada awal kwartal ke 3 tahun 2020 menyabutkan bahwa kapitalisasi pasar 4 Bank BUMN memiliki nilai sebesar Rp. 1.812 Triliun. Nilai kapitalisasi pasar tersebut senilai dengan 24,99\% total kapitalisasi pasar Bursa Efek Indonesia (BEI). Sehingga peranan Bank BUMN sangat strategis dalam melakukan pemulihan ekonomi setelah pandemi covid 19 nantinya.

Menurut Ermaini dan Irmanely (2014) Bank yang dapat selalu menjaga kinerjanya dengan baik terutama tingkat profitabilitasnya yang tinggi, mampu membagikan deviden dengan baik, prospek usaha dapat selalu berkembang dan dapat memenuhi prudential banking regulation dengan baik maka ada kemungkinan nilai saham dari bank dan jumlah dana pihak ketiga akan naik. Untuk itu diperlukan analisis yang lebih lanjut mengenai kinerja profitabilitas dari Bank tersebut. Bertolok dari latar belakang diatas, maka peneliti tertarik untuk meneliti lebih lanjut menggenai kinerja keuangan Bank BUMN yang terlisting di Bursa Efek Indonesia (BEI) terutama rasio - rasio profitabilitasnya pada periode 2018 sampai dengan 2020. Adapun 
judul penelitiannya yaitu Analisis Rasio Profitabilitas Perbankan di Indonesia (studi Empiris pada Bank BUMN).

\section{LANDASAN TEORITIS}

\section{Rasio Keuangan}

Menurut Kasmir (2018) Rasio keuangan merupakan kegiatan membandingkan angkaangka yang ada dalam laporan keuangan dengan cara membagi satu angka dengan angka lainnya. Perbandingan dapat dilakukan antara satu kompenen dengan kompenen dalam satu laporan keuangan atau antarkomponen yang ada diantara laporan keuangan. pendapat lainnya yaitu Husnan (2015) yang mengatakan bahwa analisis rasio keuangan adalah suatu cara yang membuat perbandingan data keuangan persuahaan menjadi lebih arti. Maksudnya yaitu rasio keuangan menjadi dasar untuk menjawab beberapa pertanyaan penting mengenai kesehatan keuangan dari perusahaan

\section{Bank}

Pengertian bank menurut Kasmir (2018) yaitu lembaga keuangan yang kegiatan usahaany adalah menghimpun dana dari masyarakat dan menyalurkannya kembali dana tersebut ke masyarakat serta memberikan jasa -jasa bank lainnya. Selain itu juga pengertian bank adalah lembaga keuangan yang usaha pokoknya adalah memberikan kredit dan jasa -jasa dalam lalu lintas pembayaran dan peredaran uang. (wiarta, 2020)

\section{Rasio Profitabilitas}

Rasio profitabilitas merupakan rasio untuk menilai kemampuan perusahaan dan mencari keuntungan. Penggunaan rasio profitabilitas dilakukan dengan menggunakan perbandingan antara berbagai komponen yang ada di laporan keuangan neraca dan laporan laba rugi. Pengukuran dilakukan untuk beberapa periode. Penggunaan seluruh atau sebagian rasio profitabilitas tergantung dari kebijakan manajemen. Semakin lengkap jenis rasio yang digunakan semakin sempurna hasil yang akan dicapai. Artinya pengetahuan tentang kondisi dan posisi profitabilitas perusahaan dapat diketahui secara sempurna. Masing-masing jenis rasio profitabilitas digunakan untuk menilai serta mengukur posisi keuangan perusahaan dalam suatu periode tertentu untuk beberapa periode 


\section{METODELOGI PENELITIAN}

Objek yang digunakan dalam penelitian ini yaitu Bank BUMN yang terdaftar di Bursa Efek Indonesia. Jenis data yang digunakan dalarn penelitian ini terdiri dari data kuantitatif yaitu data yang berupa angka-angka yang terdiri dari laporan keuangan bank BUMN yang terdaftar di Bursa Efek Indonesia, terdiri dari PT. Bank Rakyat Indonesia Tbk, PT. Bank Negara Indonesia Tbk, PT. Bank Tabungan Negara Tbk, dan PT. Bank Mandiri Tbk periode tahun 2018 samapi dengan 2020. Dalam penelitian ini pengumpulan data dilakukan dengan menggunakan dua metode sebagai berikut: Penelitian lapangan (field research), yaitu penelitian yang dilakukan dengan mengadakan pengamatan langsung terhadap laporan keuangan (objek) yang diteliti, dan Penelitian kepustakaan (library research) yaitu penelitian yang dilakukan dengan mempelajari literatur yang ada hubungannya dengan penulisan skripsi ini. Hal tersebut dimaksudkan sebagai sumber acuan untuk membahas teori yang mendasari pembahasan masalah dan analisis data yang dilakukan dalam penelitian.

\section{HASIL PENELITIAN}

Untuk memperoleh perkembangan atau kinerja hasil usaha suatu bank perlu diadakan suatu interpretasi atau analisa terhadap finansial bank yang bersangkutan. Dalam menganalisa dan menilai posisi keuangan untuk mengetahui seberapa jauh kemampuan bank dalam menghasilkan keuntungan atau laba. Maka untuk mengukur keefektifan kegiatan operasional bank dapat diketahui melalui rasio profitabilitas. Adapun kinerja rasio profitabilitas 4 bank BUMN tersebut dapat dilihat pada tabel dibawah ini: 


\begin{tabular}{|c|c|c|c|c|c|}
\hline \multicolumn{6}{|c|}{$\begin{array}{c}\text { Tabel } \\
\text { Hasil Perhitungan rasio - rasio Profitabilitas Bank BUMN Periode } 2017 \text { sampai dengan } \\
2020 .\end{array}$} \\
\hline \multirow{2}{*}{ Rasio } & \multicolumn{4}{|c|}{ Tahun } & \multirow{2}{*}{ Rata-rata } \\
\hline & 2020 & 2019 & 2018 & 2017 & \\
\hline \multicolumn{6}{|c|}{ Bank Mandiri } \\
\hline ROA & 1,64 & 3,03 & 3,17 & 2,72 & 2,64 \\
\hline ROE & 9,36 & 15,08 & 16,23 & 14,53 & 13,8 \\
\hline NIM & 4,48 & 5,46 & 5,52 & 5,63 & 5,27 \\
\hline \multicolumn{6}{|c|}{ Bank BNI } \\
\hline $\mathrm{ROA}$ & 0,5 & 2,4 & 2,8 & 2,7 & 2,1 \\
\hline ROE & 2,9 & 14 & 16,1 & 15,6 & 12,15 \\
\hline NIM & 4,5 & 4,9 & 5,3 & 5,5 & 5,05 \\
\hline \multicolumn{6}{|c|}{ Bank BTN } \\
\hline ROA & 0,69 & 0,13 & 1,34 & 1,71 & 0,97 \\
\hline ROE & 10,02 & 1 & 14,89 & 18,11 & 11,01 \\
\hline NIM & 3,06 & 3,32 & 4,32 & 4,76 & 3,87 \\
\hline \multicolumn{6}{|c|}{ Bank BRI } \\
\hline ROA & 1,98 & 3,5 & 3,68 & 3,69 & 3,21 \\
\hline ROE & 11,05 & 19,41 & 20,49 & 20,03 & 17,75 \\
\hline NIM & 6 & 6,98 & 7,45 & 7,93 & 7,09 \\
\hline
\end{tabular}

Sumber: Laporan Tahunan (data diolah)

Return on Asset merupakan rasio yang menggambarkan tingkat keuntungan (earning) yang didapatkan oleh manajemen atas total asset yang dimiliki. Return On Asset adalah rasio yang mencerminkan kesangupan bank dalam mengendalikan dana yang diinvestasikan dalam semua asset yang mendatangkan keuntungan. Berdasarkan tabel diatas, diketahui bahwa nilai rata - rata rasio ROA tertinggi sebesar 3,21 dimiliki oleh PT. Bank Rakyat Indonesia (BBRI) dan terendah oleh PT. Bank Tabungan Negara Tbk (BBTN) dengan nilai sebesar 0,97.

ROE adalah perbandingan antara laba bersih bank dengan modal sendiri. Rasio ini merupakan indikator yang sangat penting bagi para pemegang saham dan calon investor untuk mengukur kemampuan bank dalam memperoleh laba bersih yang dikaitkan dengan pembayaran deviden. Penilaian rata-rata rasio ROE menurut standar BI yaitu 5\% atau 0.05 . berdasarkan tabel diatas, dapat diketahui bahwa seluruh rasio ROE bank BUMN berada diatas standar BI dengan rata- rata ROE tertinggi pada bank BBRI dan terendah pada bank BBTN. Begitupula dengan rasio NIM. Dengan rata rata tertinggi pada bank BBRI dan terendah pada bank BBTN pada periode 2017 sampai dengan 2020. 


\section{KESIMPULAN}

Berdasarkan hasil penelitian dan pembahasan dapat disimpulkan bahwa nilai rasio profitabilitas bank BUMN selama periode 2017 sampai dengan 2020 berfluktuatif. Nilai ratarata rasio profitabilitas dari tahun 2017 sampai 2020 tertinggi mulai dari rasio ROA, ROE dan NIM diperoleh oleh PT. Bank Rakyat Indonesia Tbk (BBRI) sedangkan rata - rata terendah diperoleh oleh PT. Bank Tabungan Negara Tbk (BBTN).

\section{DAFTAR PUSTAKA}

Ermaini, E., \& Irmanelly, I. 2014. Pengaruh CAR, ROA, NPM dan LDR terhadap Pertumbuhan Laba Bank. Jurnal Development, 2(1), 19-35.

Fabozzi, F. F., \& Drake, P. P. 2010. The Basics of Finance an Introduction to Financial Markets, Business Finance, and Portfolio Management. New Jersey: John Wiley and Sons, Inc.

Ferdiansyah, M. A., \& Faisal, F. A. 2020. Faktor-Faktor Nilai Perusahaan: Kajian Berdasarkan Modal Intelektual, Pertumbuhan dan Kinerja Perusahaan. E-Jurnal Akuntansi, 30(4), 911-921.

Husnan, S. 2015. Dasar - dasar Teori Portofolio dan Analisis Sekuritas. Ed keempat. Yogyakarta: UPP STIM YKPN.

Kasmir. 2018. Analisis Laporan Keuangan. Depok: Rajawali Pers.

Nurdin, N. 2018. Analisis Pertumbuhan Ekonomi Daerah Provinsi Jambi. Eksis: Jurnal Ilmiah Ekonomi dan Bisnis, 9(1), 22-37.

Sartono. 2014. Manajemen Keuangan Teori dan Aplikasi, Edisi 4. Yogyakarta: BPFE.

Sutendi, T. K. 2018. Pengaruh Pertumbuhan perusahaan dan profitabilitas terhadap harga saham dengan kebijakan deviden sebagai variabel moderasi pada Emiten LQ 45 di BEI tahun 2013-2016.

Wiarta, I. 2020. Pengaruh Rasio Kecukupan Modal, Likuiditas Dan Operasioal Terhadap Kinerja Keuangan Bank Syariah Di Indonesia (Studi Empiris Pada Bri Syariah). Jurnal Development, 8(1), 90-95.

Wulandari, A. 2019. Pengaruh profitabilitas dan leverage terhadap nilai perusahaan dengan CSR dan kebijakan deviden sebagai variabel pemoderas. 